\title{
Minerals as additives for decreasing the toxicity of Mediterranean contaminated dredged sediments
}

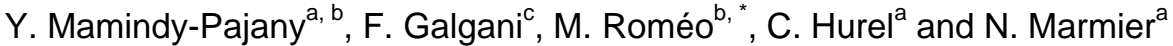

\begin{abstract}
a University of Nice Sophia-Antipolis, Faculté des Sciences, Laboratoire de Radiochimie, Sciences Analytiques et Environnement (LRSAE), BP 71, 28, Avenue Valrose, 06108 Nice Cedex 02, France

${ }^{\mathrm{b}}$ University of Nice Sophia-Antipolis, Faculté des Sciences, Ecosystèmes Marins Côtiers et Réponses aux Stress (ECOMERS/EA 4228), BP 71, 28, Avenue Valrose, 06108 Nice Cedex 02, France

${ }^{c}$ IFREMER/Laboratoire Environnement Ressources PAC/Corse Imm Agostini, ZI Furiani, 20600 Bastia, France
\end{abstract}

*: Corresponding author : M. Roméo, email address : romeo@unice.fr

\begin{abstract}
:
The management of dredged sediments is a priority issue in the Mediterranean sea where sediments are historically polluted. The aims of this study were to evaluate the toxicity of port sediment samples and the effect of three mineral additives (hematite, zerovalent iron ( $\mathrm{ZVI}$ ) and natural zeolite (NZ)) on sediment elutriate toxicity. Four sediments $(A, B, C$ and $D)$ were provided by port authorities after composting procedure; particle size, particulate organic carbon, metals and organic pollutants (TBT, PAHs, PCBs) were determined in whole sediments. Elutriates from these composted sediments were analyzed by determining toxicity level using oyster (Crassostrea gigas) larvae bioassay, metal and dissolved organic carbon concentrations. Toxicity, measured on undiluted elutriates $(250 \mathrm{~g} / \mathrm{L})$, decreased as follows: $A \geq B>C \sim D$. The treatment of sediments with mineral additives (5\%) revealed that hematite tends to decrease the elutriate toxicity in all samples, particularly in samples $B$ and $C$. This effect may be related to metal concentration decrease in elutriates, in particular $\mathrm{Cu}$ and $\mathrm{Zn}$, that have a significant toxic effect on oyster larvae. ZVI and NZ have a variable influence on elutriate toxicity. Results suggest that hematite may be a possible candidate for decreasing chemical concentration and improving the quality of elutriates. Hematite could be used for sediment stabilization prior to the deposit in a specific site or landfill.
\end{abstract}

Keywords: Dredged sediments; Crassostrea gigas larvae; Toxicity; Mineral additive; Sediment management 


\section{Introduction}

The dredging operations for coastal ports and waterways consist mainly in removing sediments to improve the ship traffic. In the world 600 million $\mathrm{m}^{3}$ (Boutin, 1999) of sediments and 50 million $\mathrm{m}^{3}$ in France (Alzieu et al., 1999) are dredged out each year from the main maritime and commercial harbours. The management of dredged sediments is a priority issue more especially in the Mediterranean sea where sediments are historically polluted (RNO, 1998). At the international level, regulations concerning dredged material and contaminated sediments are established mainly by the international commission OSPAR in the North-East Atlantic Ocean and the Barcelona convention for the Mediterranean sea. These international guidelines are translated into national criteria for marine dredged sediment management. Thus in France, the management of dredged sediments is regulated by the ministerial order of June 14th, 2000 which sets two reference concentration levels N1 and N2 for metals and PCBs in the whole sediment. These thresholds represent landmarks to evaluate the possible impact on marine ecosystems. Below level N1, the potential impact is theoretically considered as not significant, the concentrations being comparable to the environmental geochemical background. Between levels $\mathrm{N} 1$ and N2, toxicity tests are needed according to the future management. Over level N2, the discharge into the sea is forbidden and terrestrial management must be done (Alzieu and Quiniou, 2001). When contaminated sediments are discharged on terrestrial site many precautions must be taken since contaminants can be released from the deposit after waterlogging (Lions et al., 2007; Piou et al., 2009). In this context, most remediation technologies for soil or mineral ores can be used in order to limit the release of pollutants via liquid phase to aquatic ecosystems. The main stabilization process aims at enhancing metal sorption, precipitation and complexation capacity and decreasing the potential mobility or bioavailability of toxic metals in the environment. As an example, Solvay Company patented a phosphatation process (Zoubeir et al., 2007), based on the formation of apatite able to trap and fix most of heavy metals, consecutively to addition of phosphoric acid in sediment. Indeed, apatite added to a contaminated sediment immobilized almost all $\mathrm{Pb}, \mathrm{Mn}, \mathrm{Co}, \mathrm{Cu}, \mathrm{Cd}, \mathrm{Zn}, \mathrm{U}$ but some limitations for anionic species such as As, Mo and $\mathrm{Cr}$ have been highlighted (Arey et al., 1998; Seaman et al., 2001; Heinz et al., 2004).

This research investigated the possibility of reducing sediment elutriate toxicity after mixing different mineral additives with port dredged sediments which havec been already composted. Iron additives (hematite and zerovalent iron) have been studied for remediation of soils contaminated with inorganic pollutants, such as wood impregnation chemical chromated copper arsenate (CCA)-contaminated soil (Hartley et al., 2004; Kumpiene et al., 2006; Maurice et al., 2007; Kumpiene et al., 2009). Iron hydroxide can be an effective sorbent for both anions and cations since the surface of hydroxide particles can be positively or negatively charged depending on $\mathrm{pH}$ making the Fe hydroxides amphoteric (Cornell and Schwertmann, 2003). Natural zeolites, as alumino-silicate mineral, can also considered since they have characteristics of large surface area, strong capability of ion exchange and adsorption for their particular tetrahedral pore framework. Moreover, they are one of the lowcost and easily obtaining materials which have been used as adsorbent for removal of heavy metals (Babel and Kurniawan, 2003; Kocaoba et al., 2007; Gupta and Rastogi, 2008; Panuccio et al., 2008).

Among the toxicity tests considered for sediment quality assessment, the oyster (Crassostrea gigas) embryo larval development test was selected to test sediment elutriate since previous studies demonstrated that it is one of the most sensitive and rapid bioassay to check sediment samples providing sub-chronic effects (His et al., 1997; Galgani et al., 2006; Galgani et al., 2009; Mamindy-Pajany et al., 2010a). Moreover, Gourmelon et al. (2003) selected oyster embryo-larval test to study the toxicity of waters from sediment terrestrial deposit. The use of elutriates is also recommended in cases of sediment dredging activities and re-suspension phenomena in aquatic environments for their ability to give 
information on potential effects towards sensitive species including gametes, embryos and larvae (Beiras, 2002; Nendza, 2002; Quiniou et al., 2007).

Sediments were dredged from different ports along the French Riviera from Marseilles to the Italian boarder. To date this coastal area is known to be contaminated by mineral and organic compounds (Andral et al., 2004; Damiens et al., 2007), in particular, the area of Toulon (French navy harbour). In this area, the French Réseau National d'Observation : RNO (RNO, 1998) already monitored hot spots of metal in sediments from ship chandler sites. High TriButylTin (TBT) concentrations were also reported from the French Riviera (2.9 mg Sn kg ${ }^{-1}$ for sediments of Cannes port) (Cassi et al., 2008).

Sediment samples were provided in the framework of the monitoring project SEDIMARD launched in 2002 by the French public administration from the Var area in order to examine the potential issues about the management of dredged contaminated sediments in collaboration with port authorities from France and Italy. After some composting treatments, four sediment samples from Côte d'Azur area were taken into consideration. Whole composted sediments were analysed for $\mathrm{pH}$, organic carbon, metals and organic pollutants. Toxicity to oyster embryos, metals and dissolved organic carbon were measured in elutriates from composted sediments and from those treated with iron additives and natural zeolite (NZ).

\section{Materials and methods}

\subsection{Sediment dredging and sample collection}

Sediments were collected from the French Mediterranean coast using a Shipek grab and laid down over a geotextile in a terrestrial disposal site. They were actively composted for four months under sun light. During that time, once a week sediment mechanical turn over and humidification took place in order to favour the microbial activity, lower sediment salt content and decrease organotins concentrations (e.g. TBTs) (Grosdemange et al., 2008). After treatment, four homogeneous sub-samples were taken into consideration: two sediments from Côte d'Azur area (navy harbour, sample A and commercial port, sample B), and two other composite samples obtained after mixing $A$ and $B$ with several port sediments (Mamindy-Pajany et al., 2010a). All specimens were stored at $4{ }^{\circ} \mathrm{C} \pm 1{ }^{\circ} \mathrm{C}$ in the darkness before analyses. Composted sediment samples were treated by three mineral additives: hematite $(\mathrm{H})$, zero valent iron $(\mathrm{ZVI})$ and natural zeolite $(\mathrm{NZ})$ in order to evaluate the potential effect of additives on elutriate toxicity. These additives were already tested in batch and small scale experiments at three concentrations : $5,10,15 \%$, results generally showed a decrease in mineral pollutants in all cases (Mamindy-Pajany et al., 2010b) Therefore the lowest concentration (5\%) giving sufficient pollutant decreases was used. For this purpose, $50 \mathrm{~g}$ of each sediment samples (A, B, C and D) were stabilized with $5 \%$ of hematite, zerovalent iron $(\mathrm{ZVI})$ and natural zeolite (NZ). The composition of each mineral additive is presented in Table 1.

\subsection{Whole sediment physico-chemical analyses}

The water content (\%) was determined after gravimetric assessment by drying sediment samples in three replicates at $105{ }^{\circ} \mathrm{C}$ for $24 \mathrm{~h}$. The $\mathrm{pH}$ of the sediment suspensions was monitored by a WTW $\mathrm{pH}$ meter, with a combined $\mathrm{pH}$ electrode, calibrated using buffer solutions at $\mathrm{pH} 7.01$ and 4.00 at room temperature. Whole composted sediment chemical data were obtained from SEDIMARD project (Grosdemange et al., 2008). Organotins (Tributyltin TBT, Dibutyltin DBT and Monobutyltin MBT) analyses were carried out by Ultra Trace Analyses Aquitaine (UT2A) Laboratory of Pau (France): after extraction in acetic acid medium, organotin derivatization was performed by adding tetraethylborate solution and 
after centrifugations TBT was analyzed using a quadrupole instrument and Gas Chromatography-tandem Mass Spectrometry (GC-MS-MS). PAHs were analyzed using high pressure liquid chromatography HPLC 1100 (Agilent) combined with variable wavelength fluorometer. Total PAHs is defined by the sum of six PAHs (Fluoranthene, Benzo(b)fluororanthene, Benzo(k)fluoranthene, Benzo(a)pyrene, Benzo(ghi)perylene and Indeno(1,2,3-cd)pyrene). PCBs were analyzed with a gas chromatograph 6890 Agilent 5973 MSD equipped with mass spectrometry detection. Particulate organic carbon was measured by thermal oxidation followed by infra-red detection. Inorganic pollutants ( $\mathrm{As}, \mathrm{Cd}, \mathrm{Cu}, \mathrm{Mo}, \mathrm{Ni}$, $\mathrm{Pb}$, Se and $\mathrm{Zn}$ ) were determined by Inductively Coupled Plasma - Mass Spectrometry (ICPMS). Particle size distribution of composted sediments was determined by laser granulometer (Coulter ${ }^{\circledR}$ ). Granulometry size (D50) of hematite, ZVI and NZ was obtained in the same way (Mastersizer 2000, Malvern Instruments).

\subsection{Elutriate preparation}

Elutriates were prepared with seawater that was collected offshore Bastia (Corsica) and considered as reference water (Galgani et al., 2009). Reference water was filtered on 0.22 $\mu \mathrm{m}$ membrane just before use. The $1: 4$ (sediment : water) ratio was used for evaluating the potential effects of contaminated sediments. For this purpose, $5 \mathrm{~g}$ of each untreated and treated sediment samples were mixed with $20 \mathrm{~mL}$ of filtered reference water (i.e. $250 \mathrm{~g} / \mathrm{L}$ ) and shaken for $8 \mathrm{~h}$ before $8 \mathrm{~h}$ decantation.

\subsection{Elutriate chemical analyses}

The Dissolved Organic Carbon (DOC) was determined using TOC-5050 (Shimadzu). Filtered $(0.45 \mu \mathrm{m})$ samples were diluted 25 times to prevent salinity interference and inorganic carbon was stripped away through air bubbling for $30 \mathrm{~min}$ at $20 \pm 5{ }^{\circ} \mathrm{C}$ after acidification with $\mathrm{H}_{3} \mathrm{PO}_{4}$. Inorganic pollutants (As, $\mathrm{Cd}, \mathrm{Cu}, \mathrm{Mo}, \mathrm{Ni}, \mathrm{Pb}, \mathrm{Se}$ and $\mathrm{Zn}$ ) were measured by ICP-MS (ELAN DRC II) in elutriates which were filtered $(0.45 \mu \mathrm{m})$ and then acidified .

\subsection{Embryotoxicity test with Crassostrea gigas on elutriate samples}

The sub-chronic test with the oyster Crassostrea gigas larvae is based on the observation of embryo-larval development abnormalities. . Conditioned oyster adults were purchased from the Guernsey Sea Farm Ltd. hatchery (Guernsey, UK) and the test was carried out on as described by His et al. (1999). The mature genitors were carefully cleaned and immerged in unfiltered reference water at $18{ }^{\circ} \mathrm{C}$ for 30 minutes before a thermal shock $\left(28{ }^{\circ} \mathrm{C}, 30\right.$ minutes). Specimens emitting gametes were placed in 2 successive baths of filtered reference water. Fecundation was monitored under the microscope, then larvae were incubated with elutriates in the Iwaki micro-plates (300 larvae/well) at $23{ }^{\circ} \mathrm{C} \pm 1^{\circ} \mathrm{C}$ for $24 \mathrm{~h}$. After incubation, the larvae were fixed in $40 \%$ formaldehyde and decanted. The abnormality rate is determined on the basis of a count of 100 larvae per well (2-5 replicates per concentration). The Net Percentages of Abnormalities (NPA) were determined in elutriates at $250 \mathrm{~g} / \mathrm{L}$ and EC10 values (effective concentration provoking $10 \%$ of abnormalities) were calculated using the REGTOX software (Vindimian et al., 1983) after testing elutriates in the range $250-2.5 \mathrm{~g} / \mathrm{L}$. Test result acceptability was based on a) negative control giving the percentage of normal D-shape larvae $\geq 80 \%$ in filtered seawater (His et al., 1999); b) positive control : effective concentration affecting the $50 \%$ of the considered population (EC50) with respect to the reference toxicant $\left(\mathrm{Cu}\right.$ as $\left.\mathrm{Cu}\left(\mathrm{NO}_{3}\right)_{2}\right)$ falling within the acceptability range (NPA $<12 \%)$. Moreover, NPA was measured in elutriates from mineral additives $(\mathrm{H}$, $\mathrm{ZVI}$ and NZ) alone and no significant toxicity was observed. 


\subsection{Data analysis}

The GEODRISK software (Alzieu and Quiniou, 2001) was considered for data elaboration to rank sediments according to their level of chemical contamination. Statistical analyses concerning NPA values were carried out using the software XLSTAT. Data were tested for homogeneity of variance and normal distribution. One way ANOVAs were used in the analysis of toxicity data revealing statistical differences in toxicity level according to the treatment with additives. Post-hoc comparisons between elutriates from untreated and treated sediments were made using the Bonferroni's test to determine which values significantly differed.

\section{Results}

\subsection{Physico-Chemical data in whole sediments}

Physico-chemical data (water content, pH, Particulate Organic Carbon (POC) and pollutant concentrations) in whole sediments and reference levels (N1 and N2) are displayed in Table 2. Water content reaches ca $20 \%$ in $B, C$ and $D$ and is lower in $A$. The $\mathrm{pH}$ values are basic, ranging from 8.00 to 8.40 . POC ranges from $36 \mathrm{~g} \mathrm{~kg}^{-1} \mathrm{~d}$.w. in sample $D$ to $69 \mathrm{~g} \mathrm{~kg}^{-1}$ in sample A. POC values are in agreement with organic pollutant contents (PAHs, PCBs, TBT, DBT, MBT) (Table 2). Several pollutants are present in A at higher concentrations than N2 level ( $\mathrm{As}, \mathrm{Cd}, \mathrm{Cu}, \mathrm{Pb}, \mathrm{Zn}, \mathrm{TBT}, \mathrm{PAH}$ ). $\mathrm{Cu}, \mathrm{Pb}$ and $\mathrm{Zn}$ concentrations in sample $\mathrm{C}$ are higher than in sample B. Nevertheless, these metals are in higher concentration than N2 in both samples. Moreover, sample $\mathrm{C}$ is characterized by high TBT concentrations (ca one order of magnitude compared with N2 level). The lowest concentrations are found in sample D where only $\mathrm{Cu}$ and TBT are 2-fold higher than their respective N2 level. Chemical pollution decreases in composted sediments as follows: $A>C \geq B>D$. Table 3 displays the cumulative particle size distribution (from 1 to $2000 \mu \mathrm{m}$ ) of composted sediments. Particles from $B, C$ and $D$ contain more fine grains than from $A$ with the highest amount in $B(<63$ $\mu \mathrm{m})$. The fine particle distribution increases as follows: $A<C \sim D<B$.

\subsection{Chemical data in elutriates}

The treatment of sediments with additives may alter metal concentrations in elutriates (Table 4). In sample $A$, hematite only provokes a significant decrease in Mo (87\%) compared with control (untreated) A whereas ZVI increases $\mathrm{As}, \mathrm{Cu}$, Se and $\mathrm{Zn}$; NZ has no significant influence upon pollutant concentration. DOC decreases with NZ by $9 \%$ compared to control A. Compared with control B (Table 4), concentrations of $\mathrm{Cd}, \mathrm{Cu}$ and $\mathrm{Zn}$ decrease in all elutriates from stabilized sediments ( $15 \%)$. $\mathrm{Pb}$ and Mo are both decreased by $72 \%$ with hematite while NZ only has a slight effect on $\mathrm{Cu}$ and Mo (stabilization rate $\leq 10 \%$ ). ZVI decreases $\mathrm{Pb}$ level by $83 \%$ and $\mathrm{Cu}, \mathrm{Mo}$ and $\mathrm{Zn}$ to a lesser extent (stabilization rate $\leq 10 \%$ ). DOC concentrations in sample B are lowered with hematite, ZVI and NZ (6, 14 and $10 \%$, respectively). In sample $C$, hematite particularly decreases Mo and Pb levels (76 and $58 \%$, respectively) compared with control $C$ (Table 4) and concentrations of other elements decrease in the following order: As $(36 \%)>\mathrm{Cu}(30 \%)>\mathrm{Zn}(17 \%)>\mathrm{Cd}(11 \%)$. ZVI provokes As diminution (26\%), $\mathrm{Cu}$ and $\mathrm{Pb}$ (13 and $30 \%$, respectively) in elutriate $\mathrm{C}$. NZ decreases slightly both $\mathrm{Cu}$ and Mo concentrations (5\%). Compared with control C, DOC is lower in all samples and follows the order: hematite (21\%) > ZVI (11\%) > NZ (5\%). Sample $\mathrm{D}$ treated with hematite decreases Se and Zn levels (39 and $20 \%$, respectively). ZVI augments $\mathrm{As}, \mathrm{Cu}, \mathrm{Mo}, \mathrm{Ni}$ and decrease Se concentrations by $37 \%$ in elutriates while NZ has no significant effect on metal concentrations. DOC is lower in sample $D$ treated with hematite and NZ (6 and $15 \%$, respectively), a higher DOC is noted with ZVI (Table 4). 


\subsection{Toxicity tests}

Net Percentages of Abnormalities (NPA) from untreated and treated composted sediments $A, B, C$ and $D$ are shown in Fig. 1. Significance of post-hoc comparisons obtained by oneway ANOVA $(n=54 ; p<0.0001)$ is also displayed in Fig. 1 . The highest NPA is observed in elutriate from untreated sample A $(17.7 \pm 1.7 \%)$. Sample B presents the same toxicity with a higher variability. Lower toxicity (ca $10 \%$ ) is observed in samples C and D. As a result, untreated sediments have the following toxicity range : $A \geq B>C \sim D$. Compared with control (untreated) $A$, the observed toxicity in $A$ is significantly higher in sample treated with zeolite $(26.0 \pm 2.0 \%)$ than in other samples where toxicity levels are not different. The highest NPA in B that is significantly different from control B is found with NZ $(25.60 \pm 2.08$ $\%)$ whereas sample B mixed with hematite and ZVI have the lowest significant NPA (10.66 \pm $1.15 \%$ for $\mathrm{ZVI}$ ). The influence of hematite is particularly strong in sample $\mathrm{C}$ with a 3-fold decrease significantly NPA compared to control C $(9.76 \pm 0.95 \%$ versus $3.50 \pm 0.57 \%)$ whereas other additives have no effect. Results demonstrate that hematite significantly decreases toxicity of sample D $(5.75 \pm 0.5 \%)$ as well as zeolite whereas ZVI significantly increases NPA $(22.67 \pm 3.05 \%)$ compared to control D $(11.0 \pm 1.0 \%)$.

\section{Discussion}

Results of chemical pollutants in whole composted sediments confirmed that sample $A$ is significantly contaminated by TBT, metals, PAHs and PCBs. Indeed, it is located in a ship chandler zone where antifouling paints releasing $\mathrm{Cu}$ and organotins are used (Cassi et al., 2008). Conversely, sample $B$, collected from a commercial port, presented much lower pollutant concentrations especially TBT, while $\mathrm{Cu}$ content was similar to that of $\mathrm{C}$ and $\mathrm{D}$.

In this paper, GEODRISK software has been used to compute risk score (Alzieu and Quiniou, 2001) in order to evaluate the sediment contamination and potential ecotoxicological effects associated with the observed concentrations of contaminants. For this purpose, metal (As, $\mathrm{Cd}, \mathrm{Cu}, \mathrm{Ni}, \mathrm{Pb}, \mathrm{Zn}$ ) and PCB concentrations (Table 2) were input into the software to obtain risk scores. The risk score is high for $A$ (risk score $>2$ ) and the same for B and C (risk score = 2), whereas it is lower than 2 for D (Table 2). Discharge of dredged sediments from $A$ into the sea cannot be authorised, therefore sediments are considered as wastes and must be kept out of water, and consequently an impact study is required to evaluate the potential toxicity of waste elutriates. For other samples $(B, C$ and $D)$, the contaminant risk score is $\leq 2$, therefore a local impact study must be directly carried out in order to check if sediment discharge may represent the less harmful solution for the environment.

The observed toxicity towards Crassostrea gigas larvae follows the order A $\geq B>C \sim D$. Toxicity results for elutriate from sample $A$ are in good agreement with risk score based on chemical data on whole sediments. B and $C$ have the same risk score although elutriates present different levels of toxicity (different NPAs). Elutriates from $C$ and $D$, on the other hand, have the same toxicity level but these sediments do not present the same risk score. Therefore, chemical data on whole sediments do not always allow predicting their toxicity. Hence, pollutant and DOC concentrations were determined in elutriates (Table 4). Samples $A$ and $B$ present different chemical composition (Table 2 whole sediments; Table 4 elutriates) and nearly the same toxicity. In sample B, toxicity can be explained by the great amount of fine particles $(<63 \mu \mathrm{m})$, as shown in Table 3, that might have brought additional pollutants adsorbed onto residual sediment particles that provoke toxicity (Geffard, 2001; Amiard et al., 2007). The comparison between metal concentrations in elutriates and relative EC50s as single metal with C. gigas embryotoxicity test from literature could help data interpretation. If a metal concentration is up to the EC50 value, the elutriate toxicity could be 
potentially affected. Table 4 shows that $\mathrm{Cd}, \mathrm{Cu}, \mathrm{Ni}$ and $\mathrm{Zn}$ could be directly involved in the potential toxicity of all samples since their concentrations in elutriates are higher than the

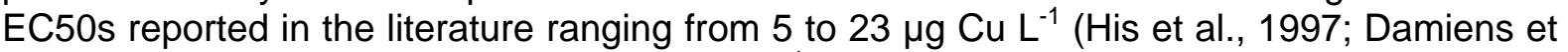

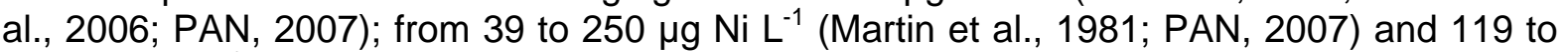
$250 \mu \mathrm{g} \mathrm{Zn} \mathrm{L}^{-1}$ (Martin et al., 1981; PAN, 2007). Arsenic and cadmium do not significantly contribute to elutriate toxicity since EC50 values for $C$. gigas ranged between 326 to $920 \mu \mathrm{g}$ As $\mathrm{L}^{-1}$ and 50 to $610 \mu \mathrm{g} \mathrm{Cd} \mathrm{L}{ }^{-1}$ (Martin et al., 1981; PAN, 2007), Moreover, Mo and Se oxyanions do not seem to participate in toxicity since they are released in low concentrations in the most toxic sample (A). However high metal concentrations in elutriates $(\mathrm{Cd}, \mathrm{Cu}, \mathrm{Ni}$, $\mathrm{Zn}$ ) are not sufficient enough to provoke $50 \%$ abnormalities in oyster larvae, suggesting that metals are not bioavailable. This can be explained by the DOC level that controls the bioavailability of metals by binding them (Di Toro et al., 2001; Santore et al., 2001; Di Toro et al., 2005) and reducing their toxicity in elutriates (Kim et al., 1999; Laodong et al., 2001). Nadella et al. (2009) demonstrated that addition of dissolved organic carbon (DOC) in natural seawater reduces $\mathrm{Cu}$ toxicity and exerts a protective effect on developing embryos of the blue mussel Mytilus trossolus. Organic compounds present in whole sediments (Table 2) have very low solubility in water and do not seem to play an important role on elutriate toxicity. Grosdemange et al. (2008) found that organic compounds are not detectable in elutriates from composted sediments (A, B, C and D).

The treatment of sediments with mineral additives aims at decreasing the potential mobility or bioavailability of toxic metals in elutriates. The effect of hematite tends to decrease toxicity in all samples, whereas ZVI and NZ have variable effects according to the sediment sample. The decrease of toxicity with hematite may be related to metal adsorption on mineral surface (Table 3). A number of workers have examined the adsorption of metals onto iron (hydr)oxides (Johnson, 1990; Cowan et al., 1991). The surface Fe atoms of these oxides are hydrated in aqueous solution by coordination with water, producing surface hydroxyl groups $(-\mathrm{OH})$. Adsorption of metals $\left(\mathrm{M}^{2+}\right)$ occurs through surface complexation reactions between the oxide surface and the dissolved metal as follows: $\mathrm{S}-\mathrm{OH}+\mathrm{M}^{2+} \rightarrow \mathrm{S}-\mathrm{OM}^{+}+\mathrm{H}^{+}$(Stumm, 1992). Results show that hematite significantly adsorbs $\mathrm{Cu}$ and $\mathrm{Zn}$ which are known as the most toxic pollutants towards oyster C. gigas larvae (His et al., 1997; Damiens et al., 2006; PAN, 2007). ZVI decreases toxicity in sample B due to a possible interaction with suspended particles in elutriate. Recent studies (Dries et al., 2005; Liu et al., 2008; Baalousha, 2009) have shown that, in addition to direct sorption on the ZVI surface, humic acid complexation with dissolved iron released from corrosion results in the formation of colloids and aggregates in solution that may affect contaminant removal. Natural Zeolite (NZ) has no significant effect on metal removal and toxicity. According to the toxicity results (Fig.1), hematite may be a possible candidate for stabilization of contaminated sediments by improving chemistry and ecotoxicological quality of elutriates. In addition, this type of additive may be available in great amounts and at low cost.

Contaminated sediments that are disposed on terrestrial site are classified as inert wastes. However, their toxicity has to be evaluated by the European $\mathrm{H} 14$ criterion giving the ecotoxicological impact. To date, there are no technical requirements at the European level. Environment Agency in England and Wales proposes to use NOECs or EC10 values from oyster embryo larval tests as one of the prime means of regulating effluent discharges to saltwater environments (Environment Agency, 1996; Worboys et al., 2002). Since the use of NOEC for chronic ecotoxicity evaluation is very criticized (Crane and Newman, 2000), mainly for statistical reasons, the EC10 (effective concentration causing $10 \%$ abnormalities) was determined for each untreated sediment and sediment treated with hematite in this paper (Table 5). Contrary to waste storage centres, the technical and regulatory requirements applicable to materials dredged from ports are still rather imprecise. One of the main techniques used consists in depositing the dredged material directly on the ground. The former is kept in place by a dike composed of permeable material to allow the water from the dredged material to drain and filter through (Perrodin et al., 2006). Due to their large quantities, dredged sediments are commonly disposed to storage sites without further treatment or precaution. However, these materials may be of environmental concern 
especially when they originate from historically contaminated areas as in Mediterranean region. The site specific liquid to sediment ratio $\mathrm{L} / \mathrm{S}_{\text {site }}$ (liter per $\mathrm{kg}$ sediments) represents the cumulative liquid to sediment ratio that can be expected to penetrate the sediment layer over the estimated time period (Kosson et al., 1996; Tack et al., 1999; Cappuyns et al., 2006). The quantity $\mathrm{Q}$ of sediments that can be stored can be estimated using $\mathrm{L} / \mathrm{S}_{\text {site, }}$, the infiltration rate I (liter per $\mathrm{m}^{2}$ ), the storage duration $\mathrm{t}$ (years): $\mathrm{Q}=(I * t) / \mathrm{L} / \mathrm{S}_{\text {site }}$

In the present work, $\mathrm{Q}$ values (expressed as $\mathrm{kg} / \mathrm{m}^{2}$ ) were calculated for each sediment (stabilized with hematite and untreated) using the sediment concentration corresponding to EC 10 values in a ten years' period of time. Under Mediterranean French weather conditions, the disposal will receive $685 \mathrm{~L} / \mathrm{m}^{2}$ of precipitation yearly (average precipitation in Toulon area). Results are shown in Table 5. The treatment with hematite decreases the L/S ratio compared with the untreated sediment. It means that for a same toxicity level in elutriates the sediment treated with hematite can be stored at higher quantities on a terrestrial site than untreated sediment. This type of treatment might serve as sediment treatment after composting procedure prior to land filling as recommended for all wastes by European Council (2002).

\section{Conclusions}

With regards to the chemical data and calculated risk score on whole sediment, contamination gradient decreases as follows: $A>C \geq B>D$. Toxicity gradient, based on net percentage of abnormalities recorded for Crassostrea gigas larvae, and which was established for elutriates prepared at the highest concentration (250 g sediments/L), is not fully in agreement with the contamination gradient: $A \geq B>C \sim D$. These results show that toxicity cannot be related only to pollutant concentrations in whole sediment but other parameters should be taken into account such as pollutant bioavailability which depends on particle size, DOC and metal concentrations in elutriates. The treatment of sediments with mineral additives (5\%) reveals that hematite tends to decrease the toxicity in all samples; the results with $\mathrm{ZVI}$ and $\mathrm{NZ}$ are variable according to the sediment sample. Hematite has a strong effect on elutriate toxicity by significantly decreasing the NPA compared to the control samples. This effect may be related to the decrease of metal concentrations in elutriates, in particular that of $\mathrm{Cu}$ and $\mathrm{Zn}$ which have a toxic effect on oyster larvae. As a result, hematite is a possible candidate for sediment stabilization by improving quality of elutriates since it adsorbs pollutants.

\section{Acknowledgement}

The authors thank Fabienne Séby and Christelle Benoit from UT2A for organotins analyses, Jean-Luc Aqua and Laurent Sannier from the SEDIMARD programme and Pierre Boissery from the "Agence de l'eau PACA" for their financial contributions to this research study.

\section{References}

Alzieu, C., Michel, P., Chiffoleau, P., Boutier, B., Abarnou, A., 1999. Dragages et environnement marin, Ifremer, Brest et Nantes, Ministère de l'Aménagement du territoire et de l'Environnement, Paris, pp. 27-35.

Alzieu, C., Quiniou, F., 2001. Géodrisk - La demarche d'analyse des risques liés à l'immersion des boues de dragage des ports maritimes, in CD-ROM Geodrisk "logiciel d'évaluation des risques liés à l'immersion des débalais de dragages des ports maritimes". 
Amiard, J.C., Geffard, A., Amiard-Triquet, C., Crouzet, C., 2007. Relationship between the lability of sediment-bound metals $(\mathrm{Cd}, \mathrm{Cu}, \mathrm{Zn})$ and their bioaccumulation in benthic invertebrates. Estuar. Coast. Shelf Sci. 72, 511-521.

Andral, B., Stanisiere, J.Y., Sauzade, D., Damier, E., Thebault, H., Galgani, F., Boissery, P., 2004. Monitoring chemical contamination levels in the Mediterranean based on the use of mussel caging. Mar. Pollut. Bull. 49, 704-712.

Arey, J.S., Seaman, J.C., Bertsch, P.M., 1998. Immobilization of Uranium in Contaminated Sediments by Hydroxyapatite Addition. Environ. Sci. Technol. 33, 337-342.

Baalousha, M., 2009. Aggregation and disaggregation of iron oxide nanoparticules: Influence of particle concentration, $\mathrm{pH}$ and natural organic matter. Sci. Total Environ. 407, 2093-2101.

Babel, S., Kurniawan, T.A., 2003. Low-cost adsorbents for heavy metals uptake from contaminated water: a review. J.Hazard. Mater. 97, 219-243.

Beiras, R., 2002. Comparison of Methods to Obtain a Liquid Phase in Marine Sediment Toxicity Bioassays with Paracentrotus lividus Sea Urchin Embryos. Arch. Environ. Contam. Toxicol. 42, 23-28.

Boutin, R., 1999. Amélioration des connaissances sur le comportement des rejets en mer des produits de dragage type vase : phénomènes court terme champ proche. Thèse de l'Institut des sciences appliquées de Lyon, France.

Cappuyns, V., Swennen, R., Devivier, A., 2006. Dredged River Sediments: Potential Chemical Time Bombs? a Case Study. Water, Air, Soil Pollut. 171, 49-66.

Cassi, R., Tolosa, I., Mora, S., 2008. A survey of antifoulants in sediments from Ports and Marinas along the French Mediterranean coast. Mar. Pollut. Bull. 56, 1943-1948.

Cornell, R., Schwertmann, U., 2003. The Iron Oxides: Structure, Properties, Reactions, Occurrences and Uses, Wiley-VCH, Weinheim, Germany.

Cowan, C.E., Zachara, J.M., Resch, C.T., 1991. Cadmium adsorption on iron oxides in the presence of alkaline earth elements. Environ. Sci. Technol. 25, 437-446.

Crane, M., Newman, M.C., 2000. What level of effect is a no observed effect? Environ. Toxicol. Chem. 19, 516-519.

Damiens, G., Mouneyrac, C., Quiniou, F., His, E., Gnassia-Barelli, M., Roméo, M., 2006. Metal bioaccumulation and metallothionein concentrations in larvae of Crassostrea gigas. Environ. Pollut. 140, 492-499.

Damiens, G., Gnassia-Barelli, M., Loquès, F., Roméo, M., Salbert, V., 2007. Integrated biomarker response index as a useful tool for environmental assessment evaluated using transplanted mussels. Chemosphere 66, 574-583.

Di Toro, D.A., H.E., Bergman, H.L., Meyer, J.S., Paquin, P.R., Santore, R.C., 2001. Biotic ligand model of the acute toxicity of metals.1 technical basis. Environ. Toxicol. Chem. 20, 2383-2396.

Di Toro, D.M., McGrath, J.A., Hansen, D.J., Berry, W.J., Paquin, P.R., Mathew, R., Wu, K.B., Santore, R.C., 2005. Predicting sediment metal toxicity using a sediment biotic ligand model: methodology and initial application. Environ. Toxicol. Chem. 24, 2410-2427.

Dries, J., Bastiaens, L., Springael, D., Kuypers, S., Agathos, S.N., Diels, L., 2005. Effect of humic acids on heavy metal removal by zero-valent iron in batch and continuous flow column systems. Water Res. 39, 3531-3540.

Environment Agency, 1996. Toxicity Based Consents Pilot Study. Environment Agency UK, Bristol, pp. 23.

European Council, 2002. Council decision of 19 December 2002 establishing criteria and procedures for the acceptance of waste at landfills pursuant to Article 16 of Annex II to Directive 1999/31/EC(2003/33/EC)

Galgani, F., Chiffoleau, J., Orsoni, V., Costantini, L., Boissery, P., Calendini, S., Andral, B., 2006. Chemical contamination and toxicity of sediments from coastal areas of Corsica islands. Chem. Ecol. 22, 299-312.

Galgani, F., Senia, J., Guillou, J., Laugier, T., Munaron, D., Andral, B., Guillaume, B., Coulet, E., Boissery, P., Brun, L., Bertrandy, M., 2009. Assessment of the Environmental Quality of 
French Continental Mediterranean Lagoons with Oyster Embryo Bioassay. Arch. Environ. Contam. Toxicol. 57, 540-551.

Geffard, O., 2001. Toxicité potentielle des sédiments marins et estuariens contaminés: évaluation chimique et biologique, biodisponibilité des contaminants sédimentaires. Thèse de l'université de Bordeaux, France.

Gourmelon, M., Le Saux, J.C., Bassoullet, P., Erard-Le Denn, E., Le Cann, P., L'Yavanc, J., Boutier, B., P., M., Quiniou, F., Alzieu, C., 2003. Bioévaluation de la qualité environnementale des sédiments portuaires et des zones d'immersion. Alzieu, C. (ed), IFREMER, Brest, pp. 215-242.

Grosdemange, D., Leveque, F., Drousie, D., Aqua, J.L., Mehu, J., Bazin, C., 2008. The SEDIMARD project : presentation and results. Lille, France.

Gupta, V., Rastogi, A., 2008. Biosorption of lead (II) from aqueous solutions by nonliving algal biomass Oedogonium sp. and Nostoc sp. - a comparative study. Colloid. Surface. B. 64, 170-178.

Hartley, W., Edwards, R., Lepp, N.W., 2004. Arsenic and heavy metal mobility in iron oxideamended contaminated soils as evaluated by short- and long-term leaching tests. Environ. Pollut. 131, 495-504.

Heinz, G.H., Hoffman, D.J., Audet, D.J., 2004. Phosphorus Amendment Reduces Bioavailability of Lead to Mallards Ingesting Contaminated Sediments. Arch. Environ. Contam. Toxicol. 46, 534-541.

His, E., Seaman, M., Beiras, R., 1997. A simplification of the bivalve embryogenesis and larval development bioassay method for water quality assessment. Water Res. 31, 351-355. His, E., Beiras, R., Seaman, M., 1999. The assessment of marine pollution-bioassays with bivalve embryos and larvae. Adv. Mar. Biol. 37, 1-178.

Johnson, B.B., 1990. Effect of $\mathrm{pH}$, temperature, and concentration on the adsorption of cadmium on goethite. Environ. Sci. Technol. 24, 112-118.

Kim, S.D., Ma, H., Allen, H.E., Cha, D.K., 1999. Influence of dissolved organic matter on the toxicity of copper to Ceriodaphnia dubia: effect of complexation kinetics. Environ. Toxicol. Chem. 18, 2433-2437.

Kocaoba, S., Orhan, Y., Akyüz, T., 2007. Kinetics and equilibrium studies of heavy metal ions removalby use of natural zeolite. Desalination 214, 1-10.

Kosson, D.S., van der Sloot, H.A., Eighmy, T.T., 1996. An approach for estimation of contaminant release during utilization and disposal of municipal waste combustion residues. J. Hazard. Mater. 47, 43-75.

Kumpiene, J., Ore, S., Renella, G., Mench, M., Lagerkvist, A., Maurice, C., 2006. Assessment of zerovalent iron for stabilization of chromium, copper, and arsenic in soil. Environ. Pollut. 144, 62-69.

Kumpiene, J., Ragnvaldsson, D., Lövgren, L., Tesfalidet, S., Gustavsson, B., Lättström, A., Leffler, P., Maurice, C., 2009. Impact of water saturation level on arsenic and metal mobility in the Fe-amended soil. Chemosphere 74, 206-215.

Laodong, G., Becky J, H., Peter H, S., Sammy M, R., 2001. Effect of Dissolved Organic Matter on the Uptake of Trace Metals by American Oysters. Environ. Sci. Technol. 35, 885893.

Lions, J., van der Lee, J., Guérin, V., Bataillard, P., Laboudigue, A., 2007. Zinc and cadmium mobility in a 5-year-old dredged sediment deposit: Experiments and modelling. J. Soils Sediments 7, 207-215.

Liu, T., Tsang, D.C.W., Lo, I.M.C., 2008. Chromium(VI) Reduction Kinetics by Zero-Valent Iron in Moderately Hard Water with Humic Acid: Iron Dissolution and Humic Acid Adsorption. Environ. Sci. Technol. 42, 2092-2098.

Mamindy-Pajany, Y., Libralato, G., Roméo, M., Hurel, C., Losso, C., Ghirardini, A.V., Marmier, N., 2010a. Ecotoxicological evaluation of Mediterranean dredged sediment ports based on elutriates with oyster embryotoxicity tests after composting process. Water Res. 44, 1986-1994.

Mamindy-Pajany, Y., Hurel, C., Roméo, M., Marmier, N., 2010b. Leaching tests and arsenic immobilization in contaminated harbour sediment. Eur. J. Environ. Civil Eng. 14, 233-251. 
Martin, M., Osborn, K.E., Billig, P., Glickstein, N., 1981. Toxicities of ten metals to Crassostrea gigas and Mytilus edulis embryos and Cancer magister larvae. Mar. Pollut. Bull. 12, 305-308.

Maurice, C., Lidelöw, S., Gustavsson, B., Lättström, A., Ragnvaldsson, D., Leffler, P., Lövgren, L., Tesfalidet, S., Kumpiene, J., 2007. Techniques for the stabilisation and assessment of treated CCA-contaminated soil. Ambio 36, 430-436.

Nendza, M., 2002. Inventory of marine biotest methods for the evaluation of dredged material and sediments. Chemosphere 48, 865-883.

Nadella, S.R., Fitzpatrick, J.L., Franklin, N., Bucking, C., Smith, S., Wood, C.M., 2009. Toxicity of dissolved $\mathrm{Cu}, \mathrm{Zn}, \mathrm{Ni}$ and $\mathrm{Cd}$ to developing embryos of the blue mussel (Mytilus trossolus) and the protective effect of dissolved organic carbon. Comp. Biochem. Physiol., C 149, 340-348.

PAN, 2007. PAN Pesticides Database - Chemical Toxicity Studies on Aquatic Organisms. http://www.pesticideinfo.org

Panuccio, M., Crea, F., Sorgonà, A., Cacco, G., 2008. Adsorption of nutrients and cadmium by different minerals: Experimental studies and modelling. J. Environ. Manage. 88, 890-898.

Perrodin, Y., Babut, M., Bedell, J.-P., Bray, M., Clement, B., Delolme, C., Devaux, A., Durrieu, C., Garric, J., Montuelle, B., 2006. Assessment of ecotoxicological risks related to depositing dredged materials from canals in northern France on soil. Environ. Int. 32, 804814.

Piou, S., Bataillard, P., Laboudigue, A., Férard, J.-F., Masfaraud, J.-F., 2009. Changes in the geochemistry and ecotoxicity of a $\mathrm{Zn}$ and $\mathrm{Cd}$ contaminated dredged sediment over time after land disposal. Environ. Res. 109, 712-720.

Quiniou, F., Damiens, G., Gnassia-Barelli, M., Geffard, A., Mouneyrac, C., Budzinski, H., Roméo, M., 2007. Marine water quality assessment using transplanted oyster larvae. Environ. Int. 33, 27-33.

RNO, 1998. Surveillance du milieu marin. Travaux du Réseau National d'Observation. IFREMER et Ministère de l'Aménagement du Territoire et de l'Environnement, Nantes, France.

Santore, R.C., Di Toro, D.M., Paquin, P.R., Allen, H.E., Meyer, J.S., 2001. Biotic ligand model of the acute toxicity of metals. Application to acute copper toxicity in freshwater fish and Daphnia. Environ. Toxicol. Chem. 20, 2397-2402.

Seaman, J.C., Arey, J.S., Bertsch, P.M., 2001. Immobilization of Nickel and Other Metals in Contaminated Sediments by Hydroxyapatite Addition. J. Environ. Qual. 30, 460-469.

Stumm, W., 1992. Chemistry of the Solid-Water Interface, New York.

Tack, F.M.G., Singh, S.P., Verloo, M.G., 1999. Leaching behaviour of $\mathrm{Cd}, \mathrm{Cu}, \mathrm{Pb}$ and $\mathrm{Zn}$ in surface soils derived from dredged sediments. Environ. Pollut. 106, 107-114.

Vindimian, E., Robaut, C., Fillion, G., 1983. A method for co-operative and non co-operative 650 binding studies using non-linear regression analysis on a microcomputer $\mathrm{J}$. Appl. Biochem. 5, 261- 268.

Worboys, M.A., Leung, K.M.Y., Grist, E.P.M., Crane, M., 2002. Time should be considered in developmental ecotoxicity test. Mar. Pollut. Bull. 45, 92-99.

Zoubeir, L., Adeline, S., Laurent, C.S., Yoann, C., Truc, H.T., Benoît, L.G., Federico, A., 2007. The use of the Novosol process for the treatment of polluted marine sediment. J. Hazard. Mater. 148, 606-612. 


\section{Tables}

Table 1. Composition of mineral additives

\begin{tabular}{cccc}
\hline Additive & D50 $(\mu \mathrm{m})$ & Supplier & Composition \\
& & & \\
\hline Hematite (H) & 0.77 & Alfa Aesar & $99.5 \%$ \\
Zerovalent Iron (ZVI) & 16.9 & Sigma Aldrich & $99.9 \%$ \\
Natural & & & Clinoptilolite 84\% \\
Zeolite (NZ) & 7.2 & Zeochem & Cristobalite 8\% \\
& & (France) & Feldspars 4\% \\
& & & Illite 4\%
\end{tabular}


Table 2. Chemical composition of sediments on a dry weight basis. Risk score is computed with GEODRISK software. N1 and N2 (metals and PCBs) levels in the whole sediment from the French order of June 14th, 2000. N1 and N1 for PAH (sum of PAHs) and TBT concentrations are provisory values.

\begin{tabular}{|c|c|c|c|c|c|c|c|}
\hline $\begin{array}{l}\text { Sediment } \\
\text { Samples }\end{array}$ & & A & B & C & $\mathrm{D}$ & N1 & N2 \\
\hline Water content & $\%$ & $15.6 \pm 1.6$ & $27.2 \pm 2.7$ & $25.4 \pm 2.5$ & $21.3 \pm 2.1$ & & \\
\hline $\mathrm{pH}$ & & $8.40 \pm 0.02$ & $8.40 \pm 0.02$ & $8.00 \pm 0.02$ & $8.30 \pm 0.02$ & & \\
\hline POC & $\mathrm{g} \mathrm{kg}^{-1} \mathrm{~d} . \mathrm{m}$ & $69 \pm 7$ & $45 \pm 4$ & $43 \pm 4$ & $36 \pm 4$ & & \\
\hline As & $\mathrm{mg} \mathrm{kg}^{-1} \mathrm{~d} . \mathrm{m}$. & $114 \pm 11$ & $43 \pm 4$ & $35 \pm 3$ & $14 \pm 1$ & 25 & 50 \\
\hline $\mathrm{Cd}$ & $\mathrm{mg} \mathrm{kg}^{-1} \mathrm{~d} . \mathrm{m}$. & $4.0 \pm 0.4$ & $1.1 \pm 0.1$ & $1.5 \pm 0.1$ & $0.8 \pm 0.1$ & 1.2 & 2.4 \\
\hline $\mathrm{Cu}$ & $\mathrm{mg} \mathrm{kg}^{-1} \mathrm{~d} . \mathrm{m}$. & $1,089 \pm 109$ & $241 \pm 24$ & $362 \pm 36$ & $174 \pm 17$ & 45 & 90 \\
\hline Mo & $\mathrm{mg} \mathrm{kg}^{-1} \mathrm{~d} . \mathrm{m}$. & $12 \pm 1$ & $18 \pm 2$ & $11 \pm 1$ & $16 \pm 2$ & - & - \\
\hline $\mathrm{Ni}$ & $\mathrm{mg} \mathrm{kg}^{-1} \mathrm{~d} . \mathrm{m}$. & $30 \pm 3$ & $30 \pm 3$ & $16 \pm 2$ & $19 \pm 2$ & 37 & 74 \\
\hline $\mathrm{Pb}$ & $\mathrm{mg} \mathrm{kg}^{-1} \mathrm{~d} . \mathrm{m}$. & $1,272 \pm 127$ & $271 \pm 27$ & $400 \pm 40$ & $116 \pm 12$ & 100 & 200 \\
\hline Se & $\mathrm{mg} \mathrm{kg}^{-1} \mathrm{~d} . \mathrm{m}$. & $<2$ & $<2$ & $<2$ & $<2$ & - & - \\
\hline $\mathrm{Zn}$ & $\mathrm{mg} \mathrm{kg}^{-1} \mathrm{~d} . \mathrm{m}$. & $2,659 \pm 266$ & $611 \pm 61$ & $865 \pm 86$ & $242 \pm 24$ & 276 & 552 \\
\hline MBT & $\mu \mathrm{g} \mathrm{Sn} \mathrm{kg}{ }^{-1}$ & $2,126 \pm 213$ & $166 \pm 17$ & $452 \pm 45$ & $382 \pm 38$ & - & - \\
\hline DBT & $\mu \mathrm{g} \mathrm{Sn} \mathrm{kg}{ }^{-1}$ & $1,028 \pm 103$ & $165 \pm 16$ & $935 \pm 93$ & $562 \pm 56$ & - & - \\
\hline TBT & $\mu \mathrm{g} \mathrm{Sn} \mathrm{kg}{ }^{-1}$ & $6,398 \pm 640$ & $323 \pm 32$ & $3,001 \pm 300$ & $941 \pm 94$ & 100 & 400 \\
\hline PAHs & $\mathrm{mg} \mathrm{kg}^{-1} \mathrm{~d} . \mathrm{m}$ & $31.34 \pm 3.00$ & 7.36 & 9.33 & 2.80 & 1.5 & 15 \\
\hline PCBs & $\mathrm{mg} \mathrm{kg}^{-1} \mathrm{~d} . \mathrm{m}$ & $0.73 \pm 0.07$ & $0.31 \pm 0.03$ & $0.41 \pm 0.04$ & $0.24 \pm 0.02$ & 0.5 & 1 \\
\hline Risk score & - & 2.7 & 2 & 2 & 1.3 & & \\
\hline
\end{tabular}


Table 3. Particle size cumulative distribution in sediment samples A, B, C and D.

\begin{tabular}{|c|c|c|c|c|c|}
\hline \multicolumn{6}{|c|}{ Sediment samples } \\
\hline $\begin{array}{l}\text { Particle } \\
(\mu \mathrm{m})\end{array}$ & size & A & B & C & D \\
\hline 1 & & 0.46 & 1.51 & 0.50 & 0.50 \\
\hline 2 & & 1.37 & 4.21 & 1.48 & 1.47 \\
\hline 10 & & 7.47 & 18.6 & 7.14 & 7.11 \\
\hline 63 & & 21.8 & 59.9 & 28.4 & 28.2 \\
\hline 125 & & 28.4 & 79.7 & 47.6 & 46.6 \\
\hline 250 & & 38.6 & 90.8 & 70.2 & 68.5 \\
\hline 500 & & 56.5 & 95.7 & 86.7 & 94.4 \\
\hline 1000 & & 63.2 & 99.5 & 95.9 & 94.5 \\
\hline 2000 & & 100 & 100 & 100 & 100 \\
\hline
\end{tabular}


Table 4. Chemical concentrations in elutriates of sediments $(250 \mathrm{~g} / \mathrm{L})$ and of sediments treated with $5 \%$ additives hematite $(\mathrm{H})$, zerovalent iron $(\mathrm{ZVI})$ and natural zeolite (NZ). DOC : dissolved organic carbon ( $\mathrm{n}=3$ in each sample)

\begin{tabular}{|c|c|c|c|c|c|c|c|c|c|c|c|c|c|c|c|c|}
\hline \multirow{2}{*}{$\begin{array}{l}\text { Samples } \\
\text { Additives }\end{array}$} & \multicolumn{4}{|c|}{ Sample A } & \multicolumn{4}{|c|}{ Sample B } & \multicolumn{4}{|c|}{ Sample C } & \multicolumn{4}{|c|}{ Sample D } \\
\hline & Untreated & $\mathrm{H}$ & $\mathrm{ZVI}$ & $\mathrm{NZ}$ & $\begin{array}{c}\text { Untreate } \\
\text { d }\end{array}$ & $\mathrm{H}$ & $\mathrm{ZVI}$ & $\mathrm{NZ}$ & $\begin{array}{c}\text { Untreate } \\
\mathrm{d}\end{array}$ & $\mathrm{H}$ & ZVI & $\mathrm{NZ}$ & Untreated & $\mathrm{H}$ & $\mathrm{ZVI}$ & $\mathrm{NZ}$ \\
\hline & & $44.3 \pm$ & $43.5 \pm$ & & $32.6 \pm 0.7$ & $30.6 \pm 0.3$ & $28.2 \pm 0.6$ & $29.3 \pm 0.2$ & 42.7 & $33.7 \pm 0.4$ & 38.2 & 40.8 & $31.7 \pm 0.3$ & $29.8 \pm 0.5$ & $33.2 \pm 0.4$ & 26.9 \\
\hline $\begin{array}{c}\mathrm{DOC} \\
\mathrm{mg} \mathrm{L}^{-1} \\
\text { As }\end{array}$ & $43.8 \pm 0.5$ & 0.9 & 0.9 & $40.1 \pm 0.7$ & & & & & \pm 0.2 & & \pm 0.5 & \pm 0.4 & & & & \pm 0.2 \\
\hline $\begin{array}{c}\mu \mathrm{g} \mathrm{L}^{-1} \\
\mathrm{Cd}\end{array}$ & $7 \pm 2$ & $27 \pm 2$ & $37 \pm 2$ & $9 \pm 3$ & $39 \pm 4$ & $36 \pm 2$ & $38 \pm 3$ & $40 \pm 2$ & $42 \pm 2$ & $27 \pm 7$ & $31 \pm 7$ & $48 \pm 2$ & $20 \pm 5$ & $44 \pm 4$ & $47 \pm 3$ & $26 \pm 4$ \\
\hline $\begin{array}{c}\mu \mathrm{g} \mathrm{L}^{-1} \\
\mathrm{Cu}\end{array}$ & $49 \pm 1$ & $56 \pm 2$ & $51 \pm 1$ & $52 \pm 1$ & $18 \pm 0.1$ & $15 \pm 1$ & $17 \pm 1$ & $18 \pm 1$ & $27 \pm 1$ & $24 \pm 2$ & $26 \pm 2$ & $31 \pm 1$ & $6 \pm 1$ & $8 \pm 1$ & $11 \pm 1$ & $5.5 \pm 0.1$ \\
\hline $\begin{array}{c}\mu \mathrm{g} \mathrm{L}^{-1} \\
\mathrm{Mo}\end{array}$ & $251 \pm 3$ & $269 \pm 1$ & $334 \pm 2$ & $239 \pm 3$ & $106 \pm 2$ & $88 \pm 1$ & $94 \pm 2$ & $96 \pm 2$ & $240 \pm 1$ & $169 \pm 24$ & $208 \pm 22$ & $\begin{array}{c}229 \pm 1 \\
342 \pm\end{array}$ & $58 \pm 6$ & $105 \pm 3$ & $132 \pm 2$ & $55 \pm 2$ \\
\hline $\begin{array}{c}\mu \mathrm{g} \mathrm{L}^{-1} \\
\mathrm{Ni}\end{array}$ & $70 \pm 6$ & $9 \pm 1$ & $80 \pm 2$ & $67 \pm 5$ & $510 \pm 26$ & $145 \pm 18$ & $495 \pm 18$ & $477 \pm 8$ & $365 \pm 4$ & $88 \pm 22$ & $351 \pm 16$ & 10 & $207 \pm 10$ & $195 \pm 16$ & $681 \pm 11$ & $219 \pm 4$ \\
\hline $\begin{array}{c}\mu \mathrm{g} \mathrm{L}^{-1} \\
\mathrm{~Pb}\end{array}$ & $51 \pm 2$ & $62 \pm 2$ & $57 \pm 2$ & $61 \pm 5$ & $63 \pm 2$ & $64 \pm 2$ & $72 \pm 10$ & $70 \pm 3$ & $73 \pm 2$ & $70 \pm 7$ & $72 \pm 7$ & $\begin{array}{l}82 \pm 2 \\
5.1 \pm\end{array}$ & $45 \pm 6$ & $76 \pm 3$ & $78 \pm 2$ & $55 \pm 3$ \\
\hline $\begin{array}{c}\mu \mathrm{g} \mathrm{L}^{-1} \\
\mathrm{Se}\end{array}$ & $13 \pm 1$ & $10 \pm 0.2$ & $12 \pm 0.3$ & $13 \pm 1$ & $1.8 \pm 0.5$ & $0.5 \pm 0.1$ & $0.3 \pm 0.1$ & $0.7 \pm 0.3$ & $4.7 \pm 0.5$ & $2.0 \pm 0.5$ & $3.3 \pm 0.5$ & $\begin{array}{c}0.2 \\
114 \pm\end{array}$ & $0.7 \pm 0.1$ & $<$ LD & $<$ LD & $<\mathrm{LD}$ \\
\hline $\begin{array}{c}\mu \mathrm{g} \mathrm{L}^{-1} \\
\mathrm{Zn}\end{array}$ & $34 \pm 2$ & $74 \pm 6$ & $\begin{array}{l}69 \pm 4 \\
1406 \pm\end{array}$ & $\begin{array}{c}55 \pm 11 \\
1248 \pm\end{array}$ & $105 \pm 3$ & $123 \pm 9$ & $113 \pm 8$ & $127 \pm 8$ & $65 \pm 8$ & $78 \pm 18$ & $77 \pm 16$ & $\begin{array}{c}12 \\
794 \pm\end{array}$ & $212 \pm 54$ & $130 \pm 5$ & $134 \pm 8$ & $254 \pm 11$ \\
\hline$\mu \mathrm{g} \mathrm{L}^{-1}$ & $1182 \pm 26$ & $1452 \pm 1$ & 14 & 11 & $190 \pm 4$ & $166 \pm 1$ & $176 \pm 1$ & $201 \pm 5$ & $662 \pm 2$ & $549 \pm 48$ & $622 \pm 42$ & 10 & $151 \pm 15$ & $120 \pm 1$ & $174 \pm 4$ & $166 \pm 4$ \\
\hline
\end{tabular}


Table 5. Capacity of storage of the studied sediments corresponding to a low level of toxicity over a ten years' period

\begin{tabular}{ccccc}
\hline & Treatment & EC10 & L/S & $\begin{array}{l}\text { 4.1. Q } \\
\mathbf{k g} / \mathbf{m}^{2}\end{array}$ \\
& & $($ confidence level) & Liquid/solid ratio (L/kg) \\
\hline A & Control & $2.35(2.7-2.66)$ & 426 & 16.08 \\
\hline A & Hematite & $2.39(2.15-2.60)$ & 418 & 16.40 \\
\hline B & Control & $2.00(1.62-2.39)$ & 499 & 13.73 \\
\hline B & Hematite & $2.74(2.60-2.99)$ & 365 & 18.76 \\
\hline C & Control & $2.99(2.63-3.97)$ & 334 & 20.51 \\
\hline C & Hematite & $33.73(33.63-33.77)$ & 30 & 18.48 \\
\hline D & Control & $2.69(2.41-3.31)$ & 371 & 19.42 \\
\hline D & Hematite & $2.84(2.68-6.88)$ & 353 & \\
\hline
\end{tabular}




\section{Figures}

Figure 1: Toxicity levels measured as net percentage of abnormalities (NPA) observed with Crassostrea gigas larvae in elutriates (250 g/L) from untreated and treated sediment samples. Means ( \pm 1 S.D.) with different letters differed significantly (Bonferroni tests) after significant global ANOVA.

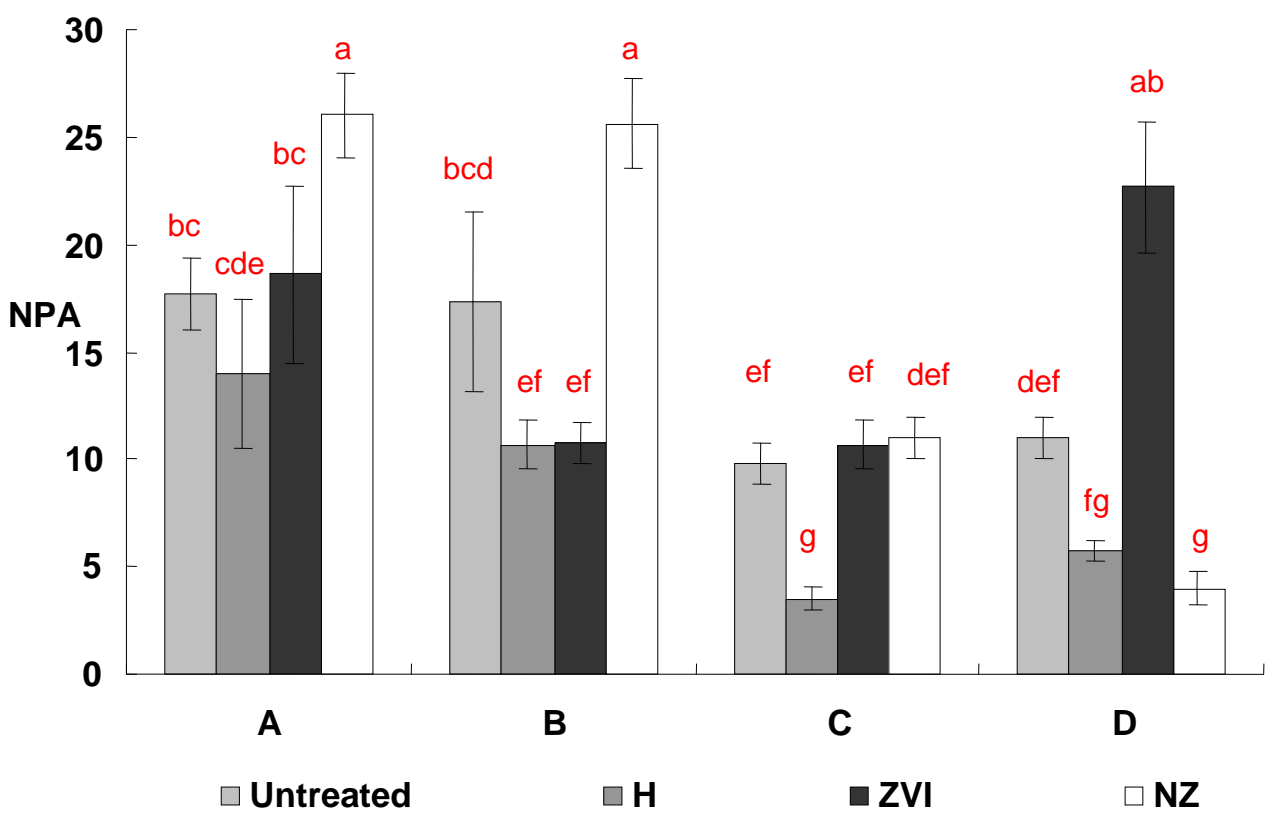

